\title{
A Revamp of the Internal Quality Auditing Process
}

\author{
Rashitah RAHMAT ${ }^{\mathrm{a}, \mathrm{b}}$, Effendi MOHAMAD ${ }^{\mathrm{a}, 1}$, Teruaki ITO $^{\mathrm{c}}$, \\ Rosidah JAAFAR $^{\mathrm{a}}$, Nor Akramin MOHAMAD ${ }^{\mathrm{a}}$ and Adi SAPTARI ${ }^{\mathrm{d}}$ \\ ${ }^{a}$ Fakulti Kejuruteraan Pembuatan,Universiti Teknikal Malaysia Melaka, \\ Hang Tuah Jaya, 76100 Durian Tunggal, Melaka, Malaysia \\ ${ }^{\mathrm{b}}$ Quality Assurance Department, SilTerra Malaysia Sdn. Bhd, Malaysia \\ 'Okayama Prefectural University, Kabuki 111, Soja-shi, Okayama 719-1197, \\ Japan \\ ${ }^{\mathrm{d}}$ Department of Industrial Engineering, President University, \\ Jl. Ki Hajar Dewantara, Kota Jababeka, Cikarang Baru, Bekasi 17550 - Indonesia
}

\begin{abstract}
In this paper, the researchers have described the development program used for the internal quality auditors of Company A. This program was developed to increase the competency of the auditors so that they could effectively conduct both internal and external audits. The competency of the auditors was an important requirement according to the various management standards like the ISO 14001:2015, ISO9001:2015, IATF 16949:2016, ISO45001:2018 and IECQ QC 0800000. Furthermore, this program exposed all the auditors to the internal audits according to the requirements of the ISO 9001 standards and the in-process quality audits, which were divided into 6 areas for 8 months. For ensuring the success of the program, $15 \%$ of the auditors' Key Responsibility Areas (KRA) were attributed to their performance and their contribution to the general internal auditing program. The different Subject Matter Experts (SME) trained the auditors based on the requirements of the managing standards and their auditing skills. A monitoring technique was established for assessing the competency level of the auditors. The auditors, who showed a good performance in these programs, were recommended to partake in the Lead Assessors program and were asked to audit local or internalexternal suppliers.
\end{abstract}

Keywords. Competent auditors; Internal quality audit; Effective auditing: Monitoring method

\section{Introduction}

Internal audit falls on clause 9.2 of various management standards such ISO 9001, ISO 14001, ISO 45001 and ISO 27001, to name a few. The extent of internal audit programme is based on size, nature and complexity of a business. According to ISO 9001 standard [1], a quality audit included a 3-step process, i.e., determination of the auditability of all planned processes with regards to the objectives of the study; conformity of the activities with the objectives; and the efficiency of the activities in

\footnotetext{
${ }^{1}$ Corresponding Author, Mail: effendi@utem.edu.my.
} 
fulfilling the objectives [2]. The internal audit must be effectively conducted for determining the operational performance of the organisation [3]. Implementation of an audit programme needs to be monitored, measured and reviewed. Mustika [4] proposed the research model based on the factors which affected the effectiveness of the internal audit process, as shown in Figure 1.

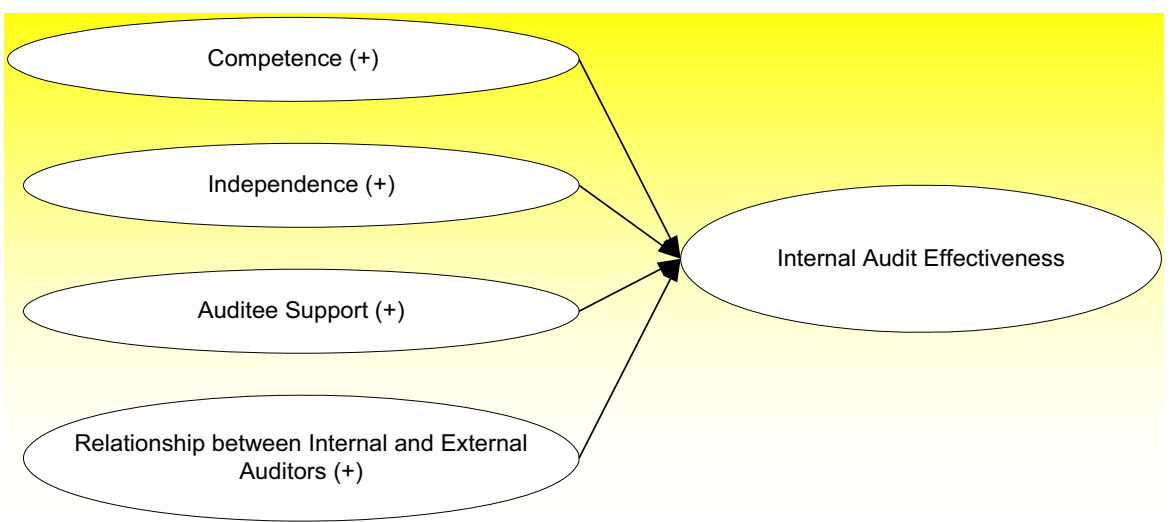

Figure 1. Factors affecting the effectiveness of the internal audit process [4]

To have a successful internal audit programme, an organization needs to have competent auditors. To ensure competency, this pool of auditors is to be evaluated regularly. The researchers studied the developmental program for internal auditors in Company A which was ISO9001 certified. In this manufacturing sector, internal auditors did not solely carry out full-time audits. Hence, performing internal audit was not a priority to the auditors. A revamp on the internal auditing program was established to have competent auditors. This was set as one of company objectives. In order to achieve this, an auditor competency program was set up.

\section{Literature Review}

The internal audit programs determine if the organisations were 'fit for their stated purposes'[2]. An earlier study Asiedu and Deffor [5] mentioned that effective internal audit sessions could detect corruption. On the other hand, Naheem [6] stated that an effective internal audit process detected money laundering processes. Kabuye et al. [7] noted that internal audits detected fraud management.

The internal audits review and monitor the operations carried out by an organisation and could suggest some steps for its improvement [8]. The use of novel technologies, processes and policies could help the organisations to ensure that the objectives of the company were fulfilled [9]. The factors which could affect the efficiency of the internal audit process included the competency, objectivity and independence of the auditors, audit reporting and planning [3,10-11]. Roussy and Brivot [12] stated that an effective internal audit process required better management support. Tackie et al. [13] observed that these factors did not affect the effectiveness of the internal audit process in the organisation. Similar results were also noted earlier [13-14].

Based on the earlier results Sari and Susanto [15] it was concluded that the competency of the auditors significantly affected the audit quality and the supply chain 
for the information systems. Work experience was required for detecting the presence of any irregularities in the system. Results noted by Shamki and Alhajri [14] showed that it could significantly affect the auditors' performance with regards to the areas they were familiar with. Furthermore, Christ et al.[16] presented a rotational program set up for the auditors which acted as a training base for improving their work experience. Competent internal auditors carried out an effective auditing process. Some of the other characteristics of effective auditors were - skilful when talking to people, the ability to establish relationships; asking questions in an intelligent manner [17]. Lee and Park [18] stated that a larger number of internal auditors in the organisation contributed to more effective audits.

Rogala [19] observed that some of the auditors failed because of unsatisfactory training levels, lesser time for preparing audits (which required combining the activities of an internal auditor and other primary activities), and finally, a lack of recognition by the organisation's management for the auditor. Nwannebuike et al. mentioned that it was better to train the internal auditors instead of developing some error-proof internal auditing processes [20]. The recruitment process used for internal auditors must be clear and transparent. The organisation's management must always motivate internal auditors and cooperate with them during the auditing process. They also need to be trained regularly for improving their auditing skills. Similar results were noted earlier by [11].

\section{Proposed framework}

The auditing scope was initiated based on the ISO9001 standard. Evaluation criteria for competency of auditors was set up by a group of Subject Matter Expert (SME).

Round 1 of the internal audit programme was done in 8 months for 6 different areas. One of the evaluation criteria for internal auditors was applying knowledge in specific disciplines in in-process areas. The in-process audits were categorised into six categories which were SERI (Special Engineering Request Instruction), TEI (Temporary Engineering Instruction), Qualification \& Recipe (Tool Qualification \& Recipe), SPC (Statistical Process Control), QRB (Qualification Review Board) and Corrective and Preventive Action System (CAPA).

The researchers selected 19 auditors from the technician and engineering levels. This pool of auditors are from different areas such as outgoing quality, in-process, quality management system, in-coming, statistical process control technicians and engineers. Auditors were initially internally trained based on the ISO9001 standard, in-process categories above and "generic" auditing processes and theories. Auditing process requires detailed planning skills. Audit dates, audit checklist and previous audit report follow up need to be prepared ahead. During audit, listening and asking questions techniques are needed to ensure audit objectives are met. After the audit, report writing skills and follow ups on action items or findings raised have to be completed to close the whole audit process.

Based on the internal audit areas scheduled, the auditor developed and submitted checklist to the SMEs for further reviewing. The SMEs reviewed this checklist and returned it for further editing or correction if needed. The SMEs then observed the complete auditing process and noted the auditing skills and performance of the auditors. After auditing process was completed, SME would review observations and comments to the auditor for future improvements. Auditor then submit audit report to SME for review before report was sent to the auditee for approval. 
The SMEs would list the details regarding the audit that must be conducted. For each auditing subject, the SMEs listed the scope and the criticality factors necessary for preparing the checklists and the items which have to be verified, as described in Table 1.

Table 1. Audit area, scope and various criticality factors.

\begin{tabular}{|c|c|c|}
\hline Audit Area & Audit Scope & Audit Criticality \\
\hline $\begin{array}{l}\text { Statistical Process } \\
\text { Control (SPC) }\end{array}$ & $\begin{array}{ll}\text { - } & \text { SPC violation } \\
\text { reduction } \\
\text { - } & \text { Cpk improvement }\end{array}$ & $\begin{array}{l}\text { - Critical parameters /repeated violators } \\
\text { captured in weekly and monthly SPC } \\
\text { violation report. }\end{array}$ \\
\hline $\begin{array}{c}\text { Corrective \& } \\
\text { Preventive Action } \\
\text { (CAPA) }\end{array}$ & $\begin{array}{l}\text { - CAPA disposition } \\
\text { Defect event }\end{array}$ & $\begin{array}{l}\text { Defect event title with highest hit (detail } \\
\text { analysis to determine more effective } \\
\text { approach) } \\
\text { - } \quad \text { Shortcut during disposition }\end{array}$ \\
\hline $\begin{array}{l}\text { Temporary } \\
\text { Engineering } \\
\text { Instruction } \\
\text { (TEI)/Special } \\
\text { Engineering } \\
\text { Instruction (SERI) }\end{array}$ & $\begin{array}{ll}\text { - } & \text { Audit category based } \\
\text { on TEI/SERI Type } \\
\text { - } & \text { In-progress TEI/SERI } \\
\text { - } & \text { Expired TEI }\end{array}$ & $\begin{array}{ll}\text { - } & \text { Evaluation run for Inline Yield Issue } \\
\text { - } & \text { Evaluation run for Process Issue } \\
\text { Evaluation run for Process } \\
\text { Optimization/Improvement } \\
\text { Evaluation run for Qualification } \\
\text { Optimization }\end{array}$ \\
\hline $\begin{array}{l}\text { Qualification (Tool } \\
\text { Qualification)/Recipe }\end{array}$ & 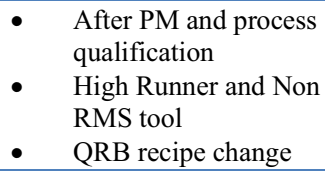 & $\begin{array}{ll}\text { - } & \text { Qualification (Tool Qualification) Audit } \\
\text { - } & \text { Tool qualification } \\
\text { - } & \text { After PM (Preventive Maintenance) Tool } \\
& \text { qualification } \\
\text { - } & \text { Recipe Audit; }\end{array}$ \\
\hline $\begin{array}{l}\text { Qualification Review } \\
\text { Board (QRB) }\end{array}$ & $\begin{array}{ll}\text { Event related to :- } \\
\text { - } & \text { Recipe Optimization } \\
\text { - } & \text { Tool qualification } \\
\text { - } & \text { Direct/ Control } \\
& \text { material qualification }\end{array}$ & $\begin{array}{l}\text { - } \quad \text { Yield improvement project } \\
\text { - } \quad \text { Insufficient data's QRB event }\end{array}$ \\
\hline
\end{tabular}

\subsection{SMEs' Audit Score Guideline}

Table 2 presents the guidelines used by the SMEs to grade the auditors with regards to every auditing procedure. 10 points were allocated for every category. A maximal of 40 points could be attained for every audit.

Table 2. Audit score guidelines.

\begin{tabular}{|l|l|l|}
\hline \multicolumn{1}{|c|}{ Areas } & Points & \multicolumn{1}{c|}{ Guidelines } \\
\hline Level of Difficulty & 5 to 7 & Audit - verification of Compliance \\
\cline { 2 - 3 } & 8 to 10 & Audit - verification of Effectiveness \\
\hline Quality of Report & 8 to 10 & Acceptable without amendments \\
\cline { 2 - 3 } & 5 to 7 & Requires minor modifications with <2 times resubmission \\
\cline { 2 - 3 } & 1 to 4 & $\begin{array}{l}\text { Requires major modifications with }>2 \text { times resubmission, direct } \\
\text { supervision required }\end{array}$ \\
\hline $\begin{array}{l}\text { Audit Preparations } \\
\text { \& Promptness }\end{array}$ & 8 to 10 & $\begin{array}{l}\text { Well prepared and on submitted ahead/onetime without much } \\
\text { assistance required }\end{array}$ \\
\cline { 2 - 3 } & 5 to 7 & $\begin{array}{l}\text { Prepared and submitted on time with certain level of assistance } \\
\text { required. }\end{array}$ \\
\cline { 2 - 3 } & 1 to 4 & $\begin{array}{l}\text { Not fully prepared, delay in report submission and heavy } \\
\text { involvement of supports required. }\end{array}$ \\
\hline Audit Process & 8 to 10 & $\begin{array}{l}\text { Covered planned audited area within time, able to grasp overall } \\
\text { system to access effectiveness }\end{array}$ \\
\cline { 2 - 3 } & 5 to 7 & Focus on compliance evidences \\
\cline { 2 - 3 } & 1 to 4 & Need SME intervention \\
\hline
\end{tabular}




\subsection{Progression of the Auditors' Skill Level}

The scores of the auditors were categorised based on their skill levels in Table 3. The SMEs were on default at Level 5 based on their auditing skill level. The progress of the auditor's process was tracked each month for determining if their skill improved.

Table 3. Skill levels of the Auditors.

\begin{tabular}{|c|c|}
\hline Level & List Of Requirements of Each Skill Level \\
\hline & $\begin{array}{l}\text { 1. Audit material know-how: } \\
\text { a. Understand basic audit requirements } \\
\text { b. Understand what a requirement is (either from ISO standard or } \\
\text { specific procedures) } \\
\text { c. Understand to put requirements into audit questionnaires } \\
\text { 2. Audit skills: } \\
\text { a. Adequate skill to ask question } \\
\text { b. Adequate skill to look for compliance evidence } \\
\text { c. Basis skill of audit report updates } \\
\text { d. Audit capabilities limited to IQA, verification compliance to } \\
\text { e. Audit capabilities limited to specific compliance audit, or simple } \\
\text { 3. Supervision required: } \\
\text { a. lose supervisor from mentor and requires input updates to ensure } \\
\text { audit performed and audit report done correctly. } \\
\text { b. Necessary coaching needed during actual audit, in terms } \\
\text { of putting proper verbal question to ask, and looking for evidences. }\end{array}$ \\
\hline & $\begin{array}{l}\text { 1. Audit material know-how: } \\
\text { - Adequate understanding audit requirements } \\
\text { - } \quad \text { Adequate understanding of linking specific requirements to ISO } \\
\text { requirements to specific procedures } \\
\text { 2. Audit skills: } \\
\text { - Able to structure audit checklist requirements } \\
\text { - } \quad \text { Able to write the audit reports correctly per audit report guidelines } \\
\text { - Audit exposure for internal ISO audit } \\
\text { - Audit capabilities limited on internal audit activities } \\
\text { 3. Supervision required: } \\
\text { - Certain level of supervision required to ensure checklist is adequate, } \\
\text { coaching during audit and modification required on audit report }\end{array}$ \\
\hline & $\begin{array}{l}\text { 1. Audit material know-how: } \\
\text { - Capable cover both Level } 1 \text { and Level } 2 \\
\text { 2. Audit skills: } \\
\text { - Capable to make judgement when to review for effectiveness of the } \\
\text { system } \\
\text { - Able to make logistical arrangement of the audit with certain } \\
\text { supervision required } \\
\text { - Audit capabilities cover up to external audit (local audits) } \\
\text { 3. Supervision required: } \\
\text { - Minimum supervision required to facilitate smoothness of the } \\
\text { - Certain level of supervision required to perform external local audits }\end{array}$ \\
\hline
\end{tabular}




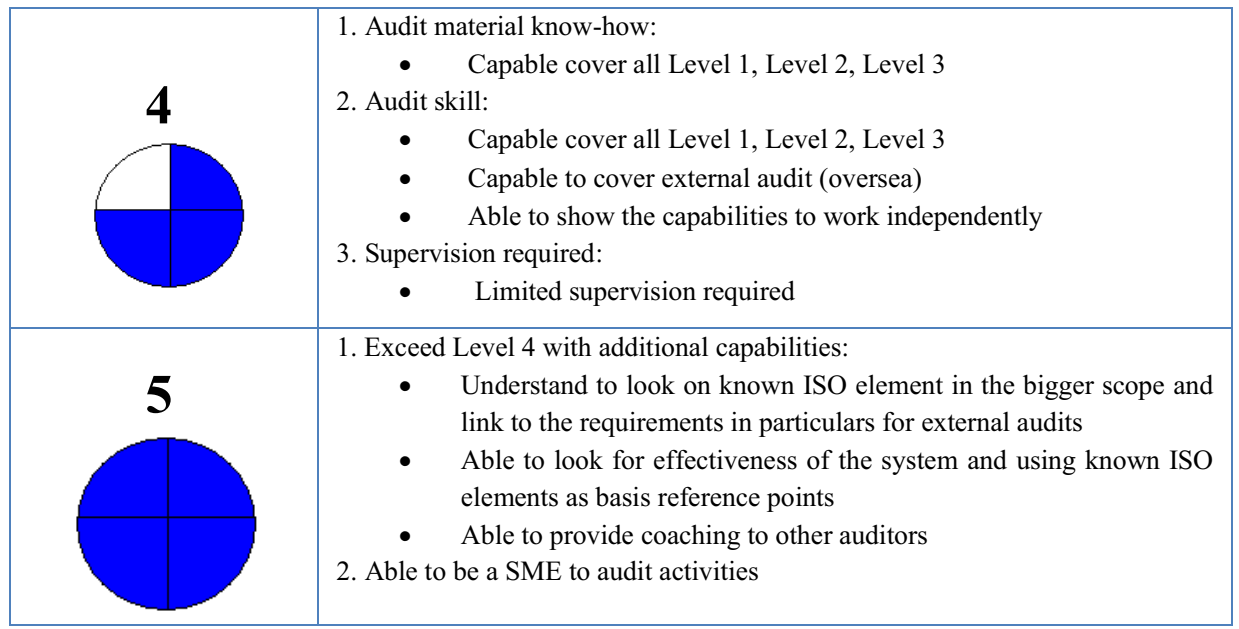

\subsection{Weightage for the KRA(Key Reseponsibility Area)}

Before initiating the audit revamp program, the structure of the program was presented to the top management for their approval. It was agreed that $15 \%$ KRA was allocated to every auditor for their annual performance appraisal. Every auditor was assigned a minimal number of audits which they had to complete every year. For SME, the management established that $20 \%$ of the KRA was to be allocated for the project. The additional allocation was set aside for every SME as they had to ensure that the objectives of the process were fulfilled by the year-end. Audit results, reports and the nonconformance reports were to be further monitored so that they could be improved. The auditor levels were identified and reported. The auditors who scored $>30$ points were recommended to undergo the lead assessor program. Thereafter, they were allowed to conduct external auditing process (which supported the incoming quality group with regards to the suppliers auditing) in the international and local organisations.

\subsection{Rotation Schedule}

Each auditor was required to conduct audit on the in-process areas specified on rotation basis monthly. Figure 2 highlights the rotation schedule for the auditors. The detailed audit item to be conducted will be prepared by the relevant SME and communicated to the auditors at the first week of the month.

\section{4. $\quad$ Results \& Discussion}

Figure 3 describes the performance of the auditors in Round 1 of the auditing process. The maximal number of audits which an auditor can conduct is 14 , while the minimum number was 5 . 


\begin{tabular}{|c|c|c|c|c|c|c|}
\hline & March & April & May & June & July & August \\
\hline \multicolumn{7}{|c|}{ Rotation Schedule } \\
\hline Auditor A & TEI & SERI & QRB & CAPA & Qual & SPC \\
\hline Auditor B & SPC & TEI & SERI & QRB & CAPA & Qual \\
\hline Auditor C & Qual & SPC & TEI & SERI & QRB & CAPA \\
\hline Auditor D & CAPA & Qual & SPC & TEI & SERI & QRB \\
\hline Auditor $\mathrm{E}$ & QRB & CAPA & Qual & SPC & TEI & SERI \\
\hline Auditor $F$ & SERI & QRB & CAPA & Qual & SPC & TEI \\
\hline Auditor $G$ & TEI & SERI & QRB & CAPA & Qual & SPC \\
\hline Auditor $\mathrm{H}$ & SPC & TEI & SERI & QRB & CAPA & Qual \\
\hline Auditor I & Qual & $\mathrm{SPC}$ & TEI & SERI & QRB & CAPA \\
\hline Auditor J & CAPA & Qual & SPC & TEI & SERI & QRB \\
\hline Auditor K & QRB & CAPA & Qual & SPC & TEI & SERI \\
\hline Auditor L & SERI & QRB & CAPA & Qual & SPC & TEI \\
\hline Auditor M & TEI & SERI & QRB & CAPA & Qual & SPC \\
\hline Auditor $\mathrm{N}$ & SPC & TEI & SERI & QRB & CAPA & Qual \\
\hline Auditor 0 & Qual & SPC & TEI & SERI & QRB & CAPA \\
\hline Auditor $\mathrm{P}$ & CAPA & Qual & SPC & TEI & SERI & QRB \\
\hline Auditor $Q$ & QRB & CAPA & Qual & SPC & TEI & SERI \\
\hline Auditor $\mathrm{R}$ & SERI & QRB & CAPA & Qual & SPC & TEI \\
\hline Auditors & TEI & SERI & QRB & CAPA & Qual & SPC \\
\hline
\end{tabular}

Figure 2. The Rotation schedule for the auditors.

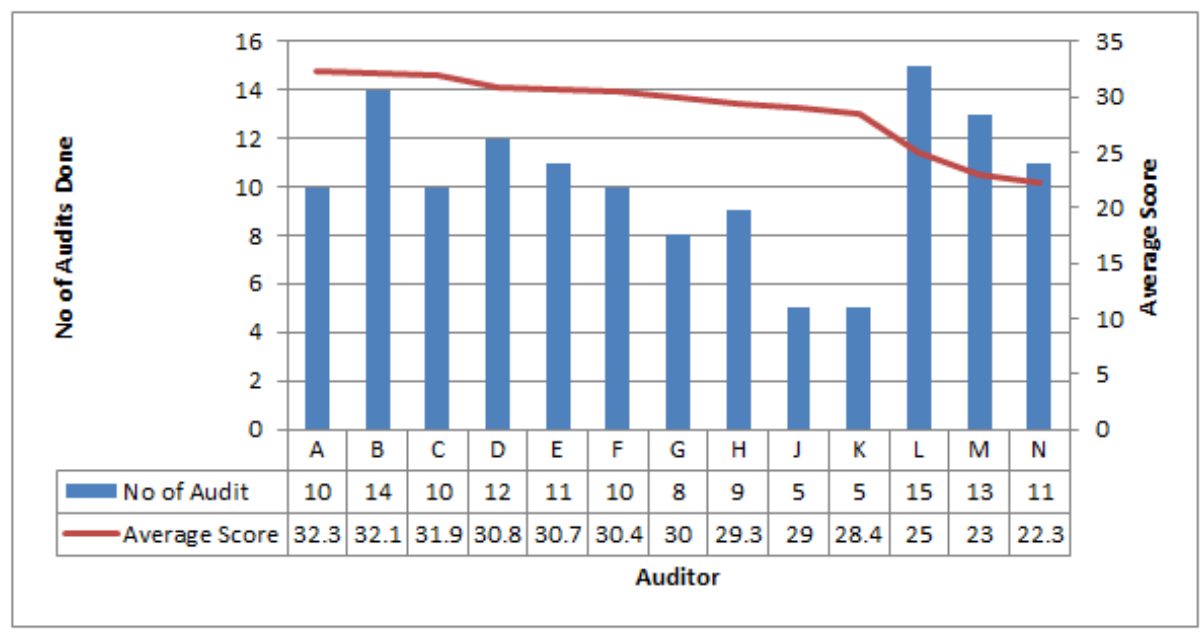

Figure 3. Performance of the auditors for Year 1 of the auditing process. 
The auditors who conducted fewer audits were technicians who worked on shifts. It was observed that technicians received lower scores than the engineers. Table 4 presents an example of the data that was collected with regards to the auditor performance based on their areas. A few audits could not be completed since there were no samples or topics that could be audited, as determined by the SMEs.

Table 4. The performance of the auditors' based on the area to be audited each month (maximum score is 40 points).

\begin{tabular}{|c|c|c|c|c|c|c|}
\hline & March & April & May & June & July & August \\
\hline SPC & 30.8 & 30.7 & 34 & 31.5 & 25.3 & 28.5 \\
\hline TEI & 26.7 & 33 & 29 & 29.5 & & \\
\hline CAPA & 31.5 & 34 & 30 & 33 & 28.5 & 24 \\
\hline QRB & 30.8 & 28.5 & 32.7 & & 32 & \\
\hline Qual & 31.8 & 27 & 32 & & & \\
\hline SERI & & 32.5 & 29 & 30.7 & 29 & 32.5 \\
\hline
\end{tabular}

The status regarding the auditors' skill and training level after Year 3 of the program was described in Table 5. The number of auditors increased by $>50 \%$. After Year 3, 4 auditors were upgraded from Skill Level 1 to Skill Level 4.

Table 5. Status of the auditors' training status based on the standards.

\begin{tabular}{|c|c|c|c|c|c|c|}
\hline Standard & $\begin{array}{c}\text { Lead } \\
\text { Assessor: } \\
\text { ISO9001 }\end{array}$ & ISO9001 & TS16949 & $\begin{array}{c}\text { IECQ QC } \\
\mathbf{0 8 0 0 0 0}\end{array}$ & $\begin{array}{c}\text { ISO } \\
\mathbf{1 4 0 0 1}\end{array}$ & OHSAS 18001 \\
\hline $\begin{array}{c}\text { No of trained / } \\
\text { certified auditors }\end{array}$ & 5 & 28 & 11 & 26 & 17 & 24 \\
\hline
\end{tabular}

Table 6 presents the number of audits which were conducted (external and internal) for 3 years. The auditing activities were seen to increase in Year 2 and decreased in Year 3 because of the business environment. In Year 2, the number of internal and external audits increased. The internal auditors with Skill 4 were selected for carrying out supplier audits, locally and internationally. This acted as a reward for auditors, who worked to upgrade their auditing skills.

Table 6. No. of audits carried out on an annual basis.

\begin{tabular}{|c|c|c|c|}
\hline Year & $\begin{array}{c}\text { No of audits done - } \\
\text { Internal }\end{array}$ & $\begin{array}{c}\text { No of supplier audits done } \\
\text { - Local }\end{array}$ & $\begin{array}{c}\text { No of supplier audits done - } \\
\text { Overseas }\end{array}$ \\
\hline Year 1 & 28 & 5 & 2 \\
\hline Year 2 & 53 & 10 & 4 \\
\hline Year 3 & 40 & 5 & 1 \\
\hline
\end{tabular}

\subsection{Moving forward}

Due to business demands, organizations now carry more than one management standard such as ISO14001 (Environmental Management System), ISO 45001 (Occupational Health and Safety Management System) and ISO 27001 (Information Security Management System). The internal auditing program can be further improved to have competent auditors who can conduct multiple management system audits in one single 
visit. Furthermore, these management systems are now aligned to one common structure. It is easier to train auditors on interpreting and auditing them. Current move now is to train auditors to conduct integrated audits. Audit resources will be better managed with this.

\section{Conclusions and Future works}

Auditors need to have good auditing skills and management standard knowledge to achieve competency. These skills include understanding the audit objective, planning, writing, listening, asking questions and following up on the findings raised during the audit. The audit revamp program set up included training and monitoring programs for auditors (engineers and technicians) from different work backgrounds. Different inprocess areas were audited on rotation basis. Subject Matter Experts who monitored the skill levels of the auditors and the standardised auditing score guidelines were part of the evaluation methods used. With practise, auditors will gain experience to perform better audits. Moving forward, organizations need to have versatile auditors who can conduct integrated audits to better manage resources. This will definitely be a bonus to the organisation.

\section{Acknowledgement}

The authors would like to thank the Malaysian Government and Universiti Teknikal Malaysia Melaka (UTeM) for their support and cooperation.

\section{References}

[1] R. Ab Wahid, Sustaining ISO 9001-based QMS in higher education: a reality?, The TQM Journal, 2019, Vol. 31, No. 4, pp. 563-577.

[2] D.Woodhouse,Quality improvement through quality audit. Quality in Higher Education, 2003, Vol.9, No. 2, pp. 133-139.

[3] N. Mahzan, and N.A.B., Hassan, Internal audit of quality in $5 \mathrm{~s}$ environment: Perception on critical factors, effectiveness and impact on organizational performance. International Journal of Academic Research in Accounting, Finance and Management Sciences, 2015, Vol.5, No.1, pp. 92-102.

[4] A.C.Mustika, Factors affecting the internal audit effectiveness. Jurnal Akuntansi dan Auditing, 2015, Vol.12, No. 2, pp. 89-109.

[5] K.F. Asiedu and E.W.Deffor, Fighting corruption by means of effective internal audit function: Evidence from the Ghanaian public sector, International Journal of Auditing, 2017, vol. 21, No.1, pp. 82-99.

[6] M.A.Naheem, Internal audit function and AML compliance: the globalisation of the internal audit function. Journal of Money Laundering Control, 2016, Vol. 19, No. 4, pp. 459-469.

[7] F.Kabuye, S.Nkundabanyanga, J.Opiso and Z.Nakabuye, Internal audit organisational status, competencies, activities and fraud management in the financial services sector, Managerial Auditing Journal, 2017, Vol. 32, No. 9, pp. 924-944.

[8] W. O.Abuazza, D. G., Mihret, K.James, and P. Best, The perceived scope of internal audit function in Libyan public enterprises, Managerial Auditing Journal, Vol.30, no.6/7, pp.560-581,2015.

[9] Z.Rezaee, Improving the quality of internal audit functions through total quality management. Managerial Auditing Journal, 1996, Vol. 11, No. 1, pp. 30-34.

[10] T.Djukic and M.Djordjevic, Needs and Specifics of Ensuring Effective Internal Audit, Facta Universitatis, Series : Economics and Organization, 2014, Vol. 11, Issue 4, pp. 353-365.

[11] K.A. Endaya and M.M. Hanefah, Internal auditor characteristics, internal audit effectiveness, and moderating effect of senior management, Journal of Economic and Administrative Sciences, 2016, Vol. 32, Issue 2, pp. 160-176. 
[12] M.Roussy and M.Brivot, Internal audit quality: a polysemous notion?, Accounting, Auditing \& Accountability Journal, 2016, Vol. 29, No. 5, pp. 714-738.

[13] G.Tackie, E. Marfo-Yiadom and S.O.Achina, Determinants of internal audit effectiveness in decentralized local government administrative systems. International Journal of Business and Management, 2016, Vol.11, No.11, pp.184-195.

[14] D. Shamki and T.A.Alhajri, Factors influence internal audit effectiveness, International Journal of Business and Management, 2017, Vol. 12, No. 10, pp. 143-154.

[15] N.Z. Sari, and A.Susanto, The Effect of Auditor Competency and Work Experience on Information Systems Audit Quality and Supply Chain (Case Study: Indonesian Bank), International Journal of Supply Chain Management, 2018, Vol. 7, No. 5, pp. 732-747

[16] M.H.Christ, A.Masli, N.Y. Sharp and D.A.Wood, Rotational internal audit programs and financial reporting quality: Do compensating controls help?, Accounting, Organizations and Society, 2015, Vol. 44, pp. 37-59.

[17] R.Lenz, G. Sarens, and F.Hoos, Internal audit effectiveness: Multiple case study research involving chief audit executives and senior management, EDPACS the EDP audit, control and security newsletter, 2017, Vol. 55, No.1, pp. 1-17.

[18] H.Y. Lee and H.Y.Park, Characteristics of the internal audit and external audit hours: evidence from S. Korea, Managerial Auditing Journal, 2016, Vol. 31, No.6/7, pp. 629-654.

[19] P.Rogala, Why Do Internal Audits Fail? The Internal Auditors'perspective, Center for Quality: 9th International Quality Conference at University of Kragujevac, 2015, pp. 367-374.

[20] U.S. Nwannebuike, E.O. Nwadialor, Evaluation of Effectiveness of Internal Audit in the Nigerian Public Sector, European Journal of Business, Economics and Accountancy, Vol. 4, No. 3, 2016, pp. 44-58. 